\title{
PHYTOCHEMISTRY AND BIOLOGICAL ACTIVITIES OF CRATEVA ADANSONII EXTRACTS
}

\author{
MARTIAL S. NOUNAGNON ${ }^{1}$, DURAND DAH-NOUVLESSOUNON ${ }^{1}$, CHRISTINE NTCHA ${ }^{1}$, BORIS LEGBA ${ }^{1}$, FARID \\ BABA-MOUSSA $^{2}$, ADOLPHE ADJANOHOUN ${ }^{3}$, LAMINE BABA-MOUSSA ${ }^{1 *}$
}

${ }^{1}$ Laboratoire de Biologie et de Typage Moléculaire en Microbiologie, Faculté des Sciences et Techniques/Université d'Abomey-Calavi, 05 BP 1604 Cotonou, Benin, ${ }^{2}$ Laboratoire de Microbiologie et de Technologies Alimentaires, Faculté des Sciences et Techniques, Université Abomey-Calavi, 04 BP: 1107 Cotonou, Benin, ${ }^{3}$ Centre de Recherche Agricole Sud. Institut National de Recherche Agricole du Benin. Attogon. BP: 884 Cotonou Benin

Email: laminesaid@yahoo.fr

Received: 08 May 2018 Revised and Accepted: 30 Jul 2018

\section{ABSTRACT}

Objective: This study aims to search the secondary metabolites of Crateva adansonii (leaves and bark) and evaluate some biological activities (antimicrobial, antioxidant and cytotoxicity's property) of these extracts.

Methods: The phytochemical screening was made with standard method. Agar diffusion method was used for antibacterial activity coupled with Minimum Inhibitory Concentration (MIC) and Bactericidal (MBC) determination. The antifungal test was performed by the mycelial development reduction method. DPPH method was used to evaluate the extracts antioxidant activity. Artemia salina larvae were use as support to evaluate the toxicity of the extracts.

Results: The results of the phytochemical screening reveal the presence of polyphenols, triterpenoids, and glycosides in the both organs (leaves and bark) of $C$. adansonii. All the extracts have low activity on the reference strains with a larger diameter of $17 \pm 00 \mathrm{~mm}(S$. oralis). Only the ethanolic and hydroethanolic leaf's extracts inhibited respectively $20 \%$ and $10 \%$, of the clinical strain $S$. aureus. The ethyl acetate leaf's extract shows the best antifungal activity $(89,19 \%)$ with A. clavatus. All extracts present dose-dependent antiradical properties and are non-toxic for the cells of Artemia salina. C. adansonii bark extracts had the best reducing power $(23,80 \pm 0,137 \mathrm{mmol} / \mathrm{g}$ EqAA EAA) of the DPPH radical.

Conclusion: $C$. adansonii is therefore an active principle source for the development of drugs to antimicrobial and antioxidant activities

Keywords: Screening phytochemical, Antimicrobial activity, Anti-radical activity, Benin

(C) 2018 The Authors. Published by Innovare Academic Sciences Pvt Ltd. This is an open access article under the CC BY license (http://creativecommons.org/licenses/by/4.0/) DOI: http://dx.doi.org/10.22159/ijpps.2018v10i9.27197

\section{INTRODUCTION}

Infectious diseases are a major public health problem around the world and particularly in Africa. They are responsible for 45 percent of deaths in countries with low income and almost a premature mortality in the world [1]. Among infectious diseases, bacterial infections are for $70 \%$ of cases of mortality caused by microorganisms [2]. Other infectious agents involved include viruses and fungi. The toxinogenes fungi that grow on food diffuse inside and develop mycotoxins which ingestion in a contaminated food case can cause poisoning to the consumer [3].

Abusive and uncontrolled use of synthesis products meant the emergence of bacteria and fungi resistant to many antibiotics and antifungals conventional [4]. Beyond infectious diseases, the harmful effects of oxidative stress on human health are a serious problem of public health [5]. Free radicals, such as the superoxides, the peroxide of hydrogen and hydroxyl ions, and Singlet oxygen, are produced in larger quantities than the antioxidants in oxidative stress in the body and this imbalance is the cause of cell damage and chronic diseases [6]. It is useful to supplement the diet by antioxidant compounds.

Traditional medicine used since the millennium by people is very useful to treat many diseases [7]. According to WHO's estimation, about $80 \%$ of African rely on traditional medicine for their medical care [8]. Currently, about $25-30 \%$ of all the drugs available for the treatment of diseases are derived from natural products [9]. Many ethnobotanical surveys in Benin and in several other countries of the sub-region show that many plants are traditionally used to treat different infectious diseases and many other chronic diseases. However, the therapeutic effects of these plants are only based on a purely empirical basis, most often without any scientific evidence.

Crataeva adansonii is a plant species of the family Capparaceae, traditionally used to treat skin infections [10]. The organs used are leaves, roots, and sometimes the bark. Some scientific research questions stem from the traditional therapeutic use of Crateva adansonii. i) What is the chemical compound involved in the pharmacological properties of $C$. adansonii? ii) These pharmacological properties vary according to the organs (leave root and bark)? iii) Are the extracts of this plant toxic? In this direction, the study aims to evaluate the phytochemistry, anti-radical, antimicrobial properties and cytotoxicity of $C$. adansonii.

\section{MATERIALS AND METHODS}

\section{Chemicals and reagents}

The solvents such as ethanol, hexane, ethyl acetate were purchased from Qualikens Fine Chem Pvt. Ltd., (Vandodara. Pin: 391340 India). 1,1-Diphenyl-2-picrylhydrazyl (DPPH), were obtained from Fluka (Neu-Ulm, Germany). Folin-Ciocalteu reagent, gallic acid were from sigma-aldrich (St. Louis, MO 63103 USA). Potato Dextrose Agar-PDA, Mueller Hinton agar, and broth were purchased from HiMedia Laboratories Pvt. Ltd, India. All other materials, chemicals, and reagents used in the experiment were of analytical grade quality.

\section{Plant material collection}

The leaves and bark of $C$. adansonii were collected in the township of Porto-Novo. These organs were air-dried in the laboratory at $25-30^{\circ} \mathrm{C}$ for $15 \mathrm{~d}$ and then ground in powder using grinder Retsch type SM 2000, 1430, Upm, Smf. The smooth powder was used to make the extracts and qualitative phytochemical screening.

\section{Qualitative phytochemical screening}

The phytochemical profiling to assess the secondary metabolites of C. adansonii leaves and bark was done according to Houghton and Rahman [11]. 


\section{Extracts preparation}

\section{Aqueous and water-ethanol extracts}

According to the method described by Dah-Nouvlessounon et al. [4], $50 \mathrm{~g}$ of powder of the leaves and the bark of Crateva adansonii, have respectively been macerated for $72 \mathrm{~h}$ at room temperature in $500 \mathrm{ml}$ of each solvent (distilled water for aqueous extract and distilled water/ethanol in 30:70 proportion for hydro-ethanol extract). The resulting homogenate was filtered three times on hydrophilic cotton and once on paper Wattman N 1 . This filtrate was then dried at $45 \mathrm{C}$ in pastor oven for aqueous extract and concentrated with rotavapor for hydro-ethanol extract. The concentrate was put in the oven at 40 ${ }^{\circ} \mathrm{C}$ until total evaporation. The resulting powder was the extracts.

\section{Successive extraction with ethanol, hexane and ethyl acetate}

The extraction method used is an adaptation to the protocol used by Sanogo et al., [12]. $50 \mathrm{~g}$ of powder of the leaves and the bark of Crateva adansonii, have respectively been macerated for $72 \mathrm{~h}$ at room temperature in $500 \mathrm{ml}$ of ethanol $96^{\circ}$. The mixture was filtered, and the half was evaporated. After adding $25 \mathrm{ml}$ of distilled water and $50 \mathrm{ml}$ of hexane to the second half, the upper organic phase was recovered and evaporated to obtaining hexanic extract. To the lower phase, $50 \mathrm{ml}$ of ethyl acetate, was added, after $30 \mathrm{~min}$ the upper phase is recovered, evaporated and dry to obtain the ethyl acetate extract. The yield of each extract was determined.

\section{Antimicrobial activity}

\section{Tested microorganisms}

These microorganisms include: 14 references strains (Sataphylococcus aureus ATCC 29213, Staphylococcus epidermidis, T22695, Micrococcus luteus, Streptococcus oralis, Enterococcus foecalis ATCC 29212, Pseudomonas aeruginosa, Proteus miriabilis A24974, Proteus vulgaris A25015, Escherichia coli ATCC 25922, Candida albicans MHMR, Aspergillus parasiticus CMBB20, Aspergillus ochraceus CMBB91, Aspergillus fumugatus CMBB89, Aspergillus clavatus NCPT 97 and 10 Staphyloccoccus strains, isolated from Buruli ulcer wounds.

\section{Sensitivity test (antibiogram)}

This test was evaluated using the disk diffusion method inspired from that described by Henry et al. [13]. Indeed, $1 \mathrm{ml}$ of bacterial culture (adjusted to $0.5 \mathrm{McF}$ arland standard) was used to flood a Petri dish containing Mueller-Hinton agar (Bio-Rad, France). Two to four sterile disks $(6 \mathrm{~mm})$ are deposited in the Petri dish previously flooded of bacterial culture under aseptic conditions. This disk was inoculated with $30 \mu \mathrm{l}$ of tested extract. For each extract, the experiment is duplicated, and negative control is performed with the solvent in place of the extract. The dishes are then kept at room temperature $15-30$ min before being incubated at $37^{\circ} \mathrm{C}$ during $24 \mathrm{~h}$ and $48 \mathrm{~h}$. The inhibition diameters were measured using a scale after incubation times of $24 \mathrm{~h}$ and $48 \mathrm{~h}$.

\section{Determination of minimum inhibitory concentration (MIC)}

The method of macro dilution with visual observation previously describe by Dah-Nouvlessounon et al. [4] was used. First, the extracts were diluted in sterilized distilled water to the highest concentration of $20000 \mu \mathrm{g} / \mathrm{ml}$ and then nine dilutions were performed to obtain the concentrations of $10000 \mu \mathrm{g} / \mathrm{ml}, 5000$ $\mu \mathrm{g} / \mathrm{ml}, 2500 \mu \mathrm{g} / \mathrm{ml}, 1250 \mu \mathrm{g} / \mathrm{ml}, 625 \mu \mathrm{g} / \mathrm{ml}, 312.5 \mu \mathrm{g} / \mathrm{ml}, 156.25$ $\mu \mathrm{g} / \mathrm{ml}, 78.12 \mu \mathrm{g} / \mathrm{ml}$ and $39.06 \mu \mathrm{g} / \mathrm{ml}$ in screw caped. To $1 \mathrm{ml}$ of the above concentrations was added $1 \mathrm{ml}$ of the bacteria inoculum $\left(10^{6}\right.$ UFC/) to obtain $2 \mathrm{ml}$ as a final volume. Culture medium without samples and others without microorganisms were used in the tests as a control. Tubes were incubated at $37^{\circ} \mathrm{C}$ for $18-24 \mathrm{~h}$ and growth was indicated by turbidity. The MIC is the lowest concentration of the compound at which the microorganism tested does not demonstrate visible growth (turbidity).

Determination of minimum bactericidal concentration (MBC)

Referring to the results of MIC test, all tubes showing no microorganism growth were identified. Each tube is inoculated into a Petri dish containing $\mathrm{MH}$ agar and incubated at $37^{\circ} \mathrm{C}$ for $24 \mathrm{~h}$. The lowest concentration of the extract in which the microorganism did not grown on solid medium is considered as Minimum Bactericidal Concentration.

\section{Evaluation of antifungal activity}

This test was evaluated by a culture method inspired of those described by Dohou et al. [14]. All extracts $(2000 \mathrm{mg} / \mathrm{ml})$ have been previously dissolved in sterile distilled water. $1 \mathrm{ml}$ was mixed with $10 \mathrm{ml}$ of agar Potato Dextrose Agar-PDA hot then sunk in Petri dishes. Extracts were then tested with a single concentration of 20 $\mathrm{mg} / \mathrm{ml}$. After solidification of the Medium, a disc (6 $\mathrm{mm}$ diameter) contaminated on one of its surfaces by the pathogen (fungal strain) was tabled in the center of petri plate. A control (control) was directed by a monoculture of the previously described as fungal strain at the center of the agar PDA (10 ml without extract). Each test is performed twice. Plates were incubated at $25 \pm 1^{\circ} \mathrm{C}$. After $5 \mathrm{~d}$ of incubation, the diameter of the mycelium was measured. The inhibition percentage was determined using the formula

\section{Antioxidant activity test: method of DDPH}

DPPH scavenging effect of $C$. adansonii extract was assessed by the method described by Kim et al. [15]. With slight modifications. A volume of $1.5 \mathrm{ml}$ of the extract solution $(10 \mu \mathrm{g} / \mathrm{ml})$ was added to $3 \mathrm{ml}$ of the methanolic solution of DPPH $(0.4 \mathrm{mg} / \mathrm{ml})$. The mixture was lifted in a dark area at room temperature for $15 \mathrm{~min}$, and then the absorbance was measured at $517 \mathrm{~nm}$ against the blank $(1.5 \mathrm{ml}$ of methanol and $3 \mathrm{ml}$ of DPPH at $10 \mu \mathrm{g} / \mathrm{ml}$ ). Radical scavenging activity was determined using a calibration curve $\left(\mathrm{R}^{2}=0.99\right)$ with ascorbic acid $(0-10 \mathrm{mg} / \mathrm{ml})$.

\section{Quantitative phytochemical screening of the bark and leaves extracts}

\section{Total phenolics content}

Total polyphenols were determined by using adapted FolinCiocalteu method as described by Singleton et al. [16]. Briefly, the methanolic solution of each extract $(10 \mathrm{mg} / \mathrm{ml})$ was diluted to $1 / 100$ with distilled water. $125 \mu \mathrm{l}$ of this solution was then mixed with 625 $\mu \mathrm{l}$ of Folin-Ciocalteu reagent $(10 \%)$. After $5 \mathrm{~min}, 500 \mu \mathrm{l}$ of aqueous sodium carbonate $\left(\mathrm{Na}_{2} \mathrm{CO}_{3} ; 75 \mathrm{~g} / \mathrm{l}\right)$ were added. After $2 \mathrm{~h}$ of incubation in the dark at the room temperature, the absorbances were measured in triplicate at $760 \mathrm{~nm}$ against a blank $(0.5 \mathrm{ml}$ FolinCiocalteu and $1 \mathrm{ml}$ of $\mathrm{Na}_{2} \mathrm{CO}_{3}$ ) with a spectrophotometer (BIOMATES 3S). The total phenolics content was determined using the plotted standard calibration curve with gallic acid $(0-10 \mathrm{mg} / \mathrm{ml})$.

\section{Cytotoxicity activity of the extracts}

The cytotoxic effect of the extracts was evaluated according to an adaptation of the method described by Farshori et al. [17]. The tests are carried out twice on $72 \mathrm{~h}$ larvae of Artemia salina. Briley, a test was constituted of 16 A. salina larvae in a $2 \mathrm{ml}$ solution containing 1 $\mathrm{ml}$ of the extract tested concentration and $1 \mathrm{ml}$ of the sea. The number of surviving larvae is counted after incubation at room temperature $(24 \mathrm{~h})$ and the $\mathrm{DL}_{50}$ was calculated using the regression line obtained from the surviving larvae in function of the extracts concentration representation.

\section{Statistical analysis}

The results of the experience were expressed as mean \pm standard deviation. Data were analyzed using Student Newman and Keuls (SNK) test and MINITAB (version 17) with the software SAS 9.2. $p$ values less than $0.05(p<0.05)$ were considered significant.

\section{RESULTS}

\section{Qualitative phytochemical screening}

The leaves and bark contain different secondary metabolites (table 1). The tannins (catechiques and Gallic), triterpenoids and reducing compounds are intensely present in the leaves than the bark. However, the alkaloids, anthocyanins, the coumarins, the cardenolides, the 0 -glycosides and the 0 -glycosides to GR are absent in the two organs (leaves and bark). 
Table 1: Composition in a secondary metabolite of the leaves and bark of $C$. adansonii

\begin{tabular}{|c|c|c|}
\hline \multirow[t]{2}{*}{ Secondary metabolites } & \multicolumn{2}{|c|}{ Composition } \\
\hline & Leaves & Bark \\
\hline Alkaloids & - & - \\
\hline Tannins & +++ & + \\
\hline Tannins catechiques & +++ & + \\
\hline Gallic tannins & +++ & + \\
\hline Flavonoid & ++ & ++ \\
\hline Anthocyanins & - & - \\
\hline Leuco-anthocyanins & + & + \\
\hline Coumarins & - & - \\
\hline Quinoniques derivatives & + & + \\
\hline Triterpenoids & +++ & ++ \\
\hline Steroids & - & - \\
\hline Cardenolides & - & - \\
\hline Cyanogeniques derivatives & - & - \\
\hline Power (IM) & $3 / 10$ & $2 / 10$ \\
\hline Reducing compounds & +++ & ++ \\
\hline Anthraceniques free & - & - \\
\hline O-glycosides & - & - \\
\hline O-glycosides to GR & - & - \\
\hline C-glycosides & ++ & ++ \\
\hline Mucilages & +++ & +++ \\
\hline
\end{tabular}

+++: Very intense; ++: Intense; +: Very intense; -: Negative

Table 2: Yields of extracts

\begin{tabular}{lll}
\hline Organs & Types of extracts & Yield (\%) \\
\hline Leaves & Aqueous & 16.7 \\
& Water-ethanolic & 10.78 \\
& Extract & 3.98 \\
& Hexanic & 0.66 \\
& Ethyl acetate & 0.88 \\
Bark & Residual alcohol & 0.74 \\
& Aqueous & 8.13 \\
& Water-ethanolic & 2.4 \\
\hline
\end{tabular}

\section{Crateva adansonii extract yields}

The leaves aqueous extract, presents the highest yield (16.7\%) while the lowest $(0.66 \%)$ was obtained with the leaves hexanic extract (table 2)

\section{Antibacterial activities of $C$. adansonii}

The bacterial strains sensibility varies according to the organs and extracts types (table 3). Indeed, some extracts such as: leave aqueous, leave hexanic, leave residual ethanolic extracts, as well as the aqueous bark extract, do not have inhibitory effect with reference strains. Besides, leaves water-ethanolic and ethyl acetate extracts inhibit the growth of $20 \%$ of the reference strains while the leaves ethanolic extract is active on $40 \%$ of these strains. For the bark extracts, water-ethanolic extract and ethanol extract are respectively inhibiting $20 \%$ and $30 \%$ of the reference strains. Generally, reference strains have a very low sensitivity to the leaves and bark extracts at $100 \mathrm{mg} / \mathrm{ml}$ (table 3).

The larger inhibitory diameter zone $(17 \pm 0.02 \mathrm{~mm})$ for active extracts was recorded with the leaves ethyl acetate extract against the growth of Streptococcus oralis. Besides, the lowest $(3 \pm 0.18 \mathrm{~mm})$ was obtained with the bark ethanolic extract (Escherichia coli). The inhibitory diameter zone of active extracts does not vary $(p>0.05)$ in the time ( 24 and $48 \mathrm{~h}$ ).

Table 3: Inhibitory diameters zones of the different extracts

\begin{tabular}{|c|c|c|c|c|c|c|c|c|c|c|c|}
\hline \multirow[t]{2}{*}{ organ } & \multirow[t]{2}{*}{ Type of extract } & \multicolumn{10}{|c|}{ Reference strains inhibitory diameters (mm) zones (mean \pm SD) } \\
\hline & & S. aur & Ps. aer & P. mir & M. lut & S. epi & P. vul & S. ora & E. foe & E. coli & C. alb \\
\hline \multirow[t]{5}{*}{ leaves } & Aqueous & 0 & 0 & 0 & 0 & 0 & 0 & 0 & 0 & 0 & 0 \\
\hline & water-ethanolic & 0 & 0 & 0 & 0 & 0 & $4 \pm 0.11$ & 0 & $5 \pm 0.01$ & 0 & 0 \\
\hline & Extract & $12 \pm 0.12$ & 0 & 0 & $5 \pm 0.04$ & $12.5 \pm 0.08$ & $9 \pm 0.17$ & 0 & 0 & 0 & 0 \\
\hline & Ethyl acetate & 0 & 0 & 0 & 0 & $14 \pm 0.3$ & 0 & $17 \pm 0.02$ & 0 & 0 & 0 \\
\hline & Hexanic & 0 & 0 & 0 & 0 & 0 & 0 & 0 & 0 & 0 & 0 \\
\hline \multirow[t]{3}{*}{ Bark } & Aqueous & 0 & 0 & 0 & 0 & 0 & 0 & 0 & 0 & 0 & 0 \\
\hline & water-ethanolic & 0 & 0 & 0 & 0 & 0 & 0 & 0 & $11 \pm 0.37$ & $4 \pm 0.17$ & 0 \\
\hline & Extract & 0 & 0 & 0 & 0 & 0 & $3 \pm 0.18$ & 0 & $13 \pm 0.08$ & $3 \pm 0.33$ & 0 \\
\hline
\end{tabular}

S. aur: Staphylococcus aureus, Ps. aer: Pseudomanas aeruginosa, P. mir: Proteus mirabilis, M. lut: Miccrococcus luteus, S. epi: Staphylococcus epidermidis, P. vul: Proteus vulgaris, S. ora: Streptococcus oralis, E. foe: Enterococcus foecalis, E. coli: Escherichia coli, C. alb: Candida albicans, Values of inhibition diameter are obtained as mean $\pm S D$. Each value is the mean of two essai $(n=2)$

Regarding the clinical strains of Staphylococcus aureus, only the leaves ethanolic, hydroethanolic extracts, and the bark ethanolic showed antibacterial activity. The inhibitory rate varies according to the extract. Indeed, the leaves ethanolic extract inhibit $20 \%$ of the growth 
of the clinical strain, while the leaves water-ethanolic extracts and the bark ethanolic extract inhibit each one $10 \%$ of the strains (table 4 ).

\section{Antifungal activity of $C$. adansonii extracts}

Fig. 1 shows that all the extracts present antagonism to the growth of the four fungal strains. The power of Mycelial development reduction varies $(p<0.01)$ according to the extracts. The SNK test (Student-Newman-Keuls) helped to build homogeneous groups of extract regarding the percentage of inhibition. The biger inhibitory percentage $(89,19 \%)$, was obtained with the leaves ethyl acetate extract on A. clavatus, while the lowest (20.69\%) was obtained by the leaves water-ethanolic extract with A. parasiticus strain (fig. 1).

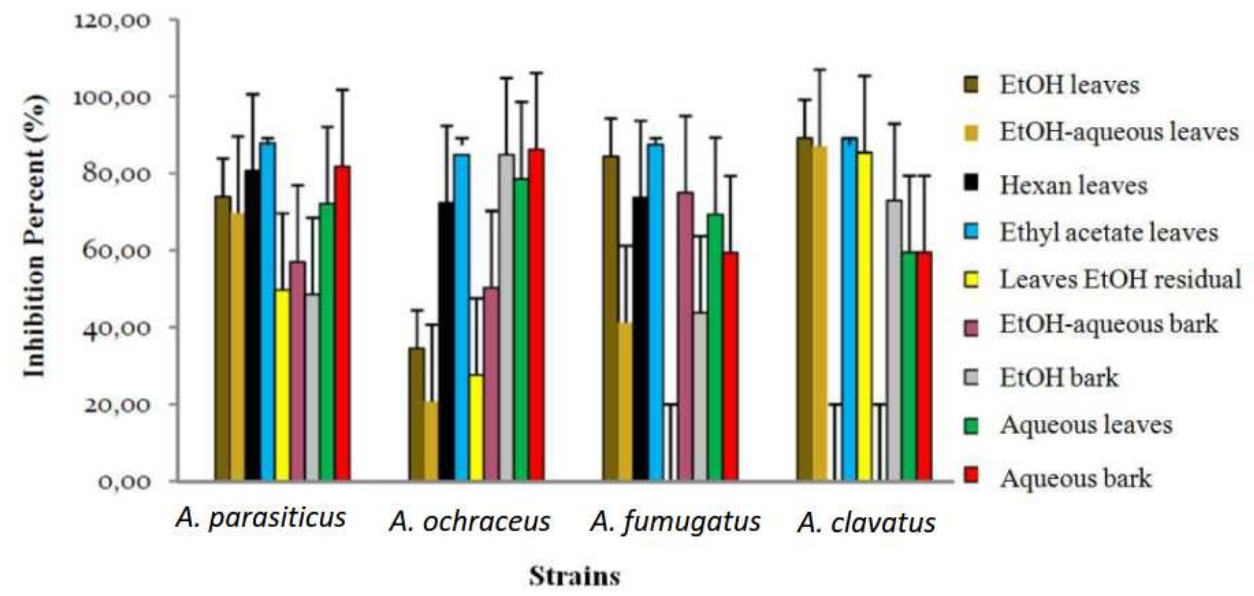

Fig. 1: Inhibitory percentage of $C$. adansonii extracts on fungal strains, values are obtained as mean \pm SD. Each value is the mean of 03 essai $(n=3)$

\section{Total polyphenols content}

Polyphenols content varies according to the extracts and the plant organs (table 5).
The leaves ethyl acetate extract has a high content (344.74 $\mu \mathrm{g}$ $\mathrm{EAG} / 100 \mathrm{mg}$ ) of total polyphenolic compounds while the leave hexanic extract recorded the lowest one (65.81 EAG $\mu \mathrm{g} / 100 \mathrm{mg}$ ).

Table 5: Total Polyphenols content of $C$. adansonii extracts

\begin{tabular}{lll}
\hline Plant organ & Extracts & Totals phenolic $(\boldsymbol{\mu g}$ EAG/100 mg) content (mean \pm SD) \\
\hline Leaves & Aqueous & $129.85 \pm 0.02$ \\
& water-ethanolic & $185.96 \pm 0.01$ \\
& Ethanolic & $132.29 \pm 0.03$ \\
& Ethyl acetate & $344.74 \pm 0.00$ \\
Residual alcohol & $71.91 \pm 0.04$ \\
& Hexanic & $65.81 \pm 0.08$ \\
Bark & Aqueous & $77.40 \pm 0.00$ \\
& water-ethanolic & $216.05 \pm 0.02$ \\
& Ethanolic & $200.60 \pm 0.01$ \\
\hline
\end{tabular}

Values are obtained as mean \pm SD. Each value is the mean of three (03) essays $(n=3)$

\section{C. adansonii anti-radical properties}

The anti-radical power of $C$. adansonii extracts with DPPH radical is expressed by the equivalent of Ascorbic acid (table 6). The biggest content $(23.8044 \pm 0.137 \mathrm{mmol} \mathrm{EAA} / \mathrm{g})$ was obtained with the bark ethanolic extract. This extract presents the largest reducing power of the DPPH radical. The leave ethanolic extract presents the lower content $(11.8271 \pm 0.008 \mathrm{mmol} \mathrm{EAA} / \mathrm{g})$.

Table 6: Equivalent ascorbic acid content of $C$. adansonii extracts

\begin{tabular}{lll}
\hline Organ & Type of extracts & Equivalent ascorbic acid (mmol EAA/g) content (mean \pm SD) \\
\hline Leaves & Aqueous & $20.2689 \pm 1.45$ \\
& water-ethanolic & $18.4522 \pm 0.09$ \\
& Ethanolic & $11.8271 \pm 0.008$ \\
& Ethyl acetate & $17.9191 \pm 0.09$ \\
& Residual ethanol & $16.0698 \pm 0.09$ \\
& Hexanic & $21.5852 \pm 0.05$ \\
Bark & Aqueous & $22.7601 \pm 0.102$ \\
& water-ethanolic & $19.9860 \pm 0.129$ \\
& Ethanolic & $23.8044 \pm 0.137$ \\
\hline
\end{tabular}

Values are obtained as mean \pm SD. Each value is the mean of three $(03)$ essay $(n=3)$ 
Table 7: Dose lethal 50 and the various extracts of Crateva adansonii regression coefficients

\begin{tabular}{llll}
\hline Plant organ & Types of extracts & LD $_{\mathbf{5 0}}(\mathbf{m g} / \mathbf{m l})$ & Regression coefficient $\left.^{\mathbf{2}} \mathbf{R}^{2}\right)$ \\
\hline Leaves & Aqueous & 5.70 & 0.7671 \\
& Water-ethanolic & 6.63 & 0.8408 \\
& Ethanolic & 4.40 & 0.9175 \\
& Hexanic & 7.41 & 0.7604 \\
& Ethyl acetate & 7.41 & 0.741 \\
& Residual alcohol & 4.34 & 0.8243 \\
Bark & Aqueous & 5.85 & 0.8652 \\
& water-ethanolic & 5.06 & 0.7144 \\
& Ethanolic & 6.37 & 0.8329 \\
\hline
\end{tabular}

\section{Larval cytotoxicity}

Table 7 shows a variation of the $\mathrm{DL}_{\mathbf{5 0}}$ from the regression line obtained from the representative curve in the number of surviving larvae based on the concentration of extracts. All the extracts have a $\mathrm{DL}_{50}$ greater than $0.1 \mathrm{mg} / \mathrm{ml}$ (table 7).

\section{DISCUSSION}

Biological activities attributed to a plant depend on its composition in bioactive compounds. Indeed, it was noted in this study a variation in the presence of various secondary metabolites groups according to the plant organs (leaves and bark). Most of the identified compounds are intensely present in the leaves and bark. However, some secondary metabolites as alkaloids are absent in $C$. adansonii leaves and bark. These results are comparable to those of Agbankpe et al. [18] Tsado et al. [19] who have highlighted the presence of alkaloids in the $C$. adansonii leaves. This difference could be due to some factors such as the type of soil [20], the location of the plants [21], the harvest of bodies [22]. The absence of cyanogenic derivatives, in the both organs, mitigates the risk of extracts toxicity because cyanogenic derivatives are the causes of toxicity due to the production of cyanide ions and which manifest through the massive poisoning resulting from ingestion of cyanogenic derivatives to acceleration and amplification of respiratory rate, respiratory depression, dizziness, headache, consciousness disorder, coma, etc. [23].

All the used solvents do not have the same extraction capacity because the yields vary according to the solvents. The variability of yields could be explained by the ability of extracting of each solvent which depends firstly on the solvent affinity with the phytomolecules and on the other hand the polarity of the solvent [4]. Unlike yields of extract that we have achieved, Nounagnon et al. [24] have found better yields (23.78\%) with water-ethanol mixture compared with the one obtained with water (9.36\%). Similarly, Agbankpe et al. [18] have found a yield of $12.7 \%$ with water and $14.3 \%$ with the water-ethanol mixture. These differences could be due to several reasons including the stage of maturity of the collected leaves [25], the extraction process, conditions of drying of the plant organs [26], the degree of purity of the used solvents.

The low antibacterial activity was observed with the tests extracts. The low antimicrobial power of the leaves aqueous and waterethanol extracts had already been mentioned by Agbankpe et al. [18], at $20 \mathrm{mg} / \mathrm{ml}$ of reference strains and strains isolated from diarrheal infections. Besides, the leaves ethyl acetate extracts have proved very active throughout the fungal strains. According to the scale of Reyes [27] for antifungal activity, the leaves ethyl acetate extract is very active, the same for the bark aqueous extract who is very active with $A$. ochraceus, and $A$. parasiticus (between 75 and $100 \%$ ) but active with $A$. fumugatus and $A$. clavatus. (between 50 and $75 \%$ ). Some strains are resistant to some extract such as: leaves hexanic, extract, leaves and bark water-ethanol extracts (between 0 and $25 \%)$. The best inhibition percentage $(89,19 \%)$ was recorded with the leaves ethyl acetate extract. Kpolali et al. [28] have shown that ethyl acetate extracts a large number of polyphenolic compounds that are also known for their antifungal properties. Similarly, Dah-Nouvlessounon et al. [4] have shown that among the organic extracts of Cola acuminata and Garcinia kola nuts ethyl acetate present best antifungal activity with Fusarium verticillioides; Aspergillus tamarii and Penicillium citrinium strains. Beyond antimicrobial activities, $C$. adansonii extracts also present interesting antiradical's properties that vary according to the extract type. The ethanol extract of the bark presents the strongest reducing power of the radical DPPH. Similar results are obtained by Moshi et al. [29] which have obvious activities in vitro antioxidant of the hydroethanol extracts of leaves of $C$. adansonii. Strong anti-radical power of the extracts could be explained by the richess in secondary metabolites of $C$. adansonii including polyphenols.

The toxicity test results show that all the extracts used are non-toxic at a concentration of $20 \mathrm{mg} / \mathrm{ml}$. Indeed, the DL ${ }_{50}$ of all the extracts are greater than $0.1 \mathrm{mg} / \mathrm{ml}$. According to the correlation grids associating the degree of toxicity with the $\mathrm{LD}_{50}$ [30], the used $C$. adansonii extracts are therefore non-toxic at $20 \mathrm{mg} / \mathrm{ml}$ to larval cells. The test according to the Artemia salina model used is a preliminary screening to determine not only the degree of toxicity of a product but also the presence of potential anti-cancer compounds. There is a correlation between cytotoxicity on shrimp larvae on 9PS and 9KB (human nasopharyngeal carcinoma) cells on the one hand [31], pulmonary carcinoma A-549 cells and HT-29 of colon carcinoma on the other hand [32]. Similarly, Lagarto-Parra et al. [33] showed a good correlation using in vitro methods, suggesting that Artemia salina test is an alternative toxicity model relatively useful.

\section{CONCLUSION}

At the end of the biological activities, we retain a low antibacterial activity at a dose of $100 \mathrm{mg} / \mathrm{ml}$, variable according to the extracts, an antifungal power considerable at a dose of $20 \mathrm{mg} / \mathrm{ml}$ on fungi of the genus Aspergillus, and anti-radical potential. This plant is, therefore, an active principle source for the development of drugs to antimicrobial and antioxidant activities, especially the cytotoxicity tests revealed its non-toxic nature towards Artemia salina larvae. The results show that $C$. adansonii is a medicinal plant with therapeutic properties and partly justify the traditional uses of this plant.

However, our work should be enhanced for better use of the medicinal plant. It will be among other things of: quantify the other secondary metabolites out of polyphenols by Spectrophotometric dosage to better categorize the potential active ingredients; expand antibacterial and antifungal to a larger number of bacterial and fungal strains, confirm the antioxidant activity by other methods and activity, optimize the toxicological aspect complementing cytotoxic in vivo toxicity tests.

\section{ACKNOWLEDGMENT}

The authors thank the government of Benin and National Center of Corn Specialization (CNS-MAÏS) of the National Institute of Agricultural Research of Benin (INRAB) for financial support.

\section{AUTHORS CONTRIBUTIONS}

Baba-Moussa Lamine: conceived and coordinated the experiments and the manuscript writing, Nounagnon S. Martial, and DahNouvlessounon Durand: conceived and designed the experiments, performed the experiments, analyzed the data and writing and editing the manuscript. N'tcha Christine and Legba Boris: analyzed the data and prepared the initial draft of the manuscript and helped in the experiment part. Baba-Moussa Farid and Adolphe Adjanohoun: Thoroughly rechecked, reviewed the manuscript and put necessary efforts to improve the quality of the manuscript. 


\section{CONFLICT OF INTERESTS}

The authors declare that they have no conflict of interests.

\section{REFERENCES}

1. Konan F, Guessennd N, Oussou KR, Bahi CA, Coulibaly, Djaman AJ, et al., Effet antibactérien de l'extrait aqueux de l'écorce de Terminalia glaucescens planch ex benth (Combretaceae) sur la croissance in vitro des enterobacteries productrices de betalactamases a spectre elargi (EBLSE). Int J Biol Chem Sci 2014; 8:1192-201.

2. Walsh C. Antibiotics: Actions, Origins, Resistance. ASM Press: Washington, DC; 2003.

3. Zohra M. Etude phytochimique et activités biologiques de quelques plantes médicinales de la région nord et sud-ouest de l'algérie. These de doctorat. Universite Abou Bekr Belkaïd; 2013.

4. Dah Nouvlessounon D, Adoukonou Sagbadja H, Diarrassouba N, Sina $\mathrm{H}$, Adjonohoun A, Inoussa $\mathrm{M}$, et al. Phytochemical analysis and biological activities of Cola nitida bark. Biochem Res Int 2015:1-12. http://dx.doi.org/10.1155/2015/493879.

5. Ahama K, Quashie MA, Agbonon I, Koumaglo K. Activites antioxydantes in vitro des feuilles de Crataeva adansonii. Rev Ivoir Sci Technol 2010;16:153-64.

6. Devasagayam TPA, Tilak JC, Boloor KK, Sane KS, Ghaskadbi SS, Lele $\mathrm{RD}$. Free radicals and antioxidants in human health: current status and future prospects. J Assoc Phys India 2004;52:794-804.

7. Sofowora A. Medicinal plants and traditional medicine in Africa, Spectrum Books Limited, Sunshine House, 2nd edition. Ibadan, Nigeria; 1993.

8. WHO. Strategie de l'OMS pour la medicine traditionnelle pour 2002-2005; 2002.

9. Fankam AG, Kuiate JR, Kuete V. Antibacterial activities of Beilschmiedia obscura and six other Cameroonian medicinal plants against multi-drug resistant gram-negative phenotypes. BMC Complement Altern Med 2014;14:241-50.

10. Adomou AC, Yedomonhan H, Conhan A, Djossa B, Legba SI, Oumorou $\mathrm{M}$, et al., Etude ethnobotanique des plantes médicinales vendues dans le marche d'Abomey-Calavi au Benin. Int J Biol Chem Sci 2012;6:745-72.

11. Houghton DJP, Raman A. Laboratory handbook for the fractionation of natural extracts. Eur J Publ 1998;71:5-102.

12. Sanogo R, Diallo D, Diarra S, Ekoumou C, Bougoudogo D. Activite antibacterienne et antalgique de deux recettes traditionnelles utilisees dans le traitement des infections urinaires et la cystite au Mali. Mali Med 2006;21:18-24.

13. Bauer AW, Kirby WM, Sherris JC, Turck M. Antibiotic susceptibility testing by a standardized single disk method. Am J Clin Pathol 1966;45:493-6.

14. Dohou N, Yamni K, Badoc A, Douira A. Activity antifongique d'extraits de Thymelaea lythroides sur Trois champignons pathogènes du riz. Bull Soc Pharm 2004;143:31-8.

15. Kim HP, Son KH, Chang HW, Kong SS. Anti-inflammatory plant flavonoids and cellular action macanism. J Pharm Sci 2004; $96: 229-54$.

16. Singleton VL, Orthofer R, Lamuela Raventos RM. Analysis of total phenols and other oxidation substrates and antioxidants by means of folin-ciocalteau reagent. Meth Enzym 1999; 299:152-78.

17. Farshori NN, Al-Oqail MM, Al-Sheddi ES, Siddiqui MA, Rauf A. Antimicrobial potentiality of polyalthia longifolia seed oil against multidrug-resistant (MDR) strains of bacteria and fungus of clinical origin. Afr J Microbiol Res 2013;19:1977-82.
18. Agbankpe AJ, Dougnon TV, Bankole SH, Houngbegnon O, DahNouvlessounon D, Baba Moussa L. In vitro antibacterial effects of Crateva adansonii, vernonia amygdalins and Sesamum radiatum used for the treatment of infections diarrheas in Benin. Infect Dis Ther 2016;4:1-7.

19. Tsado AN, Bashir L, Saba E, Saba AM, Balarabe H, Abdusalam, et al. Phytochemicals and acute toxicity profile of aqueous and methanolic extracts of Crateva adansonii leaves in swiss albino rats. J Biochem 2015;10:173-9.

20. Eldridge W, Swain W, Kwolek WF. Northen regional research center agricultural research service. U. S. Department of Agriculture, Peoria, IL 61604: and W. R. FEHR. Department of agronomy, lowa State University Ames, IA50011; 1983.

21. Salminen S, Gibson GR, Mc Cartney AL, Isolauri E. Influence of mode of delivery on gut microbiota composition in seven-yearold children. Gut 2004;53:1388-9.

22. Bruneton J. Phytochimie, plantes médicinales Les tanins. 3th ed. Editions TEC. Et DOC. Editions medicales internationales, Paris; 1999.

23. Lagnika L, Anagonou E, Atindehou M, Adjahoutonon B, Dramane K, Sanni A. Antimicrobial activity of Crateva religiosa Forst against bacteria isolated from thryonomys swinderianus temminck. Afr J Biotechnol 2011;10:10034-9.

24. Nounagnon SM, N'tcha C, Sina H, Noumavo AP, DahNouvlessounon D, Assogba MF, et al. Antimicrobial activities of Combretum micranthum extracts on Staphylococcus aureus strains isolated from skin infections and some reference strains. Asian J Plant Sci Res 2016;6:40-7.

25. Adeyemi 00, Akindele AJ, Yemitan G, Aigbe FR, Fagbo FI. Anticonvulsant, anxiolytic and sedative activities of the aqueous root extract of Securidaca longepedunculata Fresen. J Ethnopharm 2010;20:191-5.

26. Reyes GS, Brown J, Chapman J, Lugo AE. Wood densities of tropical tree species general technical report S0-88. USDA forest service, Southern Forest experiment Station, New Orléans, Louisiana, USA; 1992.

27. Rohman A, Riyanto S, Yuniarti N, Saputra WR, Utami R, Mulatsih W. Antioxidant activity, total phenolic, and total flavonoid of extracts and fractions of red fruit (Pandanus conoideus Lam). Int J Food Res 2010;17:97-106.

28. Kplolali YS, Ahama ML, Akossiwoa Q, Agbonon I, Koumaglo K. Activités antioxydantes in vitro des feuilles de crateva adansonii. Rev Ivoir Sci Technol 2010;16:153-64.

29. Moshi MJ, Cosam JC, Mbwambo ZH, Kapingu M, Nkunya MHH. Testing beyond ethnomedical claims: brine shrimp lethality of some tanzanian plants. Pharm Biol 2004;42:547-51.

30. Pelka M, Danzl C, Distler W, Petschelt A. A new screening test toxicity testing of dental materials. J Dent 2000;28:341-5.

31. Mc Lauglin JL, Chang CJ, Smith DL. Simple bench-top bioassays (brine shrimp and potato discs) for the discovery of plant antitumor compounds. In: Human Medicinal Agents from Plants. Kinghorn AD, Balandrin MF. Eds. American Chemical Society, Washington, DC; 1993.

32. Carballo JL, Hernandez-Inda ZL, Perez P, Garcia-Gràvalos MD. A comparison between two brine shrimp assays to detect in vitro cytotoxicity in marine natural products. BMC Biotech 2002; 2:17-21.

33. Lagarto Parra A, Yhebra RS, Sardinas RIG, Buela LI. Comparative study of the assay of Artemia salina L. and the estimate of the medium lethal dose $\left(\mathrm{LD}_{50}\right.$ value) in mice, to determine the acute oral toxicity of plant extracts. Phytomed 2001;8:395-400. 